\title{
Growth and yield responses of ten wheat (Triticum aestivum $L$ ) genotypes to drought
}

\author{
Shalaby, E.M.M ${ }^{1}$, E.H. Galall ${ }^{1}$, M.B. Ali ${ }^{1}$, Ahmed Amro ${ }^{2}$ and Azza El Ramly ${ }^{1, *}$ \\ ${ }^{1}$ Agronomy Department, Faculty of Agriculture, Assiut University, Assiut, 71526, Egypt \\ ${ }^{2}$ Botany and Microbiology Department, Faculty of Science, Assiut University, Assiut, 71526, Egypt
}

\begin{abstract}
In two successive seasons (2017/ 2018 and 2018 /2019), the trends of ten wheats (Triticum aestivum L) genotypes were assessed to drought stress at the Agricultural Research Station, Faculty of Agriculture, Assiut University, Egypt. Drought obtained by skipping four irrigations of seven irrigations of control. Generally, droughts caused reduction for all the estimated morphological and physiological traits. The data revealed that the plant height was greatly affected in AIL134 and Sids12. Spike length, 100 grains weight and grains yield per genotype were adversely affected in AIL103, the former was affected in Sids12 and the middle one was reduced in Giza168 under drought stress. Also photosynthetic pigments were reduced in AIL108, AIL112 and in the Egyptian genotypes (Giza168 and Sids12). On the other hand, these traits were moderately affected under drought in AIL120, AIL129, AIL142 and AIL148 genotypes. Statistical analysis revealed that the drought was significantly affected all traits except chlorophyll b contents. Also the differences between the genotypes were significant. Most of the interactions between the genotypes, treatments and years were significant with some exceptions as those for spike length and weight of 100 grains.
\end{abstract}

Keywords: Photosynthesis, Morphology, Grain yield, Spike height, Genotype.

\section{Introduction}

Wheat (Triticum aestivum L.) being one of the important staple food cereal globally, it is cultivated to rally the demands of food for population consumption in many countries of the world. Wheat is one of the major cereals in the world and is one of the main sources of calories and protein. Approximately $85 \%$ and $82 \%$ of the global population depends on wheat for basic calories and protein, respectively (Chaves et al. 2013).

\footnotetext{
*Corresponding author: Azza A. El Ramly

Email: azzaelramly2141994@yahoo.com +201203658484

Received: June 3, 2020;

Accepted: June 29, 2020;

Published: July 8, 2020.
}

It is a cereal grain belongs to Poaceae family, which has been known as semitolerant plants to drought. Wheat is grown on more than 250 million hectares and its world production is 500 million tons. Wheat is grown in many countries of the world by relying on rain water for irrigation, and in other countries it is grown using regular irrigation. The top wheat producer countries in the world are Denmark, Netherlands, France, Belgium and Germany (FAO, 2018).

Egypt had been known by wheat production and consumption since ancient times. Wheat has been cultivated by many civilizations for over 9,000 years. Recently, there was a big gap between wheat consumption and production that reached about 55\% (FAO, 2018). To 
bridge this gap Egypt imports about 6 million tons to provide for the needs of the population, as local production is not sufficient (Rizk and Sherif, 2014).

Wheat grown in widely varied climatic and edaphic conditions, but a good crop requires suitable weather conditions and adequate soil to obtain the highest yield. Slightly dry, temperate climatic conditions are most suitable for wheat cultivation. Because of its high level of adaptation, wheat is cultivated in tropical and subtropical regions and under both rain-fed and irrigated cultivation. However, crop production is severely affected by adverse environmental stresses (Rahaie et al. 2013). Wheat cultivation is subjected to a number of other limitations like diversity of climatic and soil conditions, pests and diseases. Unfavorable conditions for wheat cultivation include hail storms, heavy and prolonged rainfall, germination on spike, drought and frost. Over 100 diseases caused by biotic and abiotic stresses affect wheat in the USA and in other countries (Savary et al. 2012).

Among all the abiotic stress, drought probably has the most significant effect on growth and yield which plants may be encounter in both natural and agricultural systems (Bartels and Sunkar 2005). Drought effects all growth stages of wheat and more critical at flowering and grain filling stage. Losses of wheat productivity depend on the severity and duration of drought because of reducing in photosynthesis, stomata closure, metabolic activity decrease, oxidative stress increase and result in poor grain formation ultimately yield loss. Easy method to get yield from drought areas are to develop drought tolerance genotypes according to marks. Heritable variation required for the improvement, but heritability is low because of the genotypic and environmental interaction. Reactive oxygen species (ROS) produce as result of drought which effects the cellular mechanism, enzyme inhibition, protein degradation, effect on DNA and RNA at the end cell death (Huseynova, 2012).

Under drought conditions, chlorophyll content decreases (Nikolaeva et al., 2010) and chlorophyll $\mathrm{b}$ reduces more as compared to chlorophyll a. Meanwhile, drought tolerant genotypes have high chlorophyll content under drought stress (Keyvan, 2010). Chlorophyll content was used as marker for evaluation of germplasm. In drought chlorophyll contents decrease and stomata greatly affected. ROS negatively affect the chloroplast and cause a decrease in chlorophyll contents. Also severe drought stops the activity of photosynthesis at the end effect the chlorophyll content and photosynthetic apparatus (Mafakher et al., 2010). Photosynthetic capacity is positively correlated with leaf chlorophyll. Drought sensitive genotypes rapidly decrease chlorophyll content. Tolerant genotypes with high chlorophyll content considered as a good marker.

Drought also affects the reproductive organs, grain filling stage, pollen viability and seed development (Begcy and Walia, 2015). In recent years, agricultural management practices like irrigation and crop improvements play important role in increasing grain yield (Zhaoa et al., 2017). In cereals grain development initiate with the fertilization of egg to form zygote and one nuclei form endosperm. Photosynthesis occurs in leaves and store food in vegetative parts that play important role in grain filling. At young microspore 
stage of pollen, drought creates sterility in pollen and reduces in grain number ( $\mathrm{Ji}$ et al., 2010). In drought meiosis and anthesis are badly affected at the end reduce grain yield (Cattivelli et al., 2008). Grain number in wheat shows no effect of drought and has effect on grain filling result in shorten the grain filling stage (Farooq et al., 2014).

Different genotypes of wheat behave different in drought. A comprehensive study helps us understanding of some important markers. Breeders can select well adaptive drought genotypes on the base of morphological markers (avoid leaf senescence, flag leaf, root system, grain development, stay green character, cuticular wax and stomata conductance.), physiological markers (Abscisic acid, Proline, Chlorophyll content, Jasmonic acid and cell stability) and molecular markers (Iqbal, 2019). The final yield of any crop is well known to depend on plant performance during the successive stages of its life cycle; the most critical of which are seed germination and seedling growth (Tian et al. 2014). Evaluation and breeding of wheat genotypes tolerance or sensitivity to drought could be estimated after the performed in the following steps: (1) calculation of expected wheat productivity, depending on environmental factors, (2) calculation of relative productivity of cultivars in the environments, and (3) recommendation of cultivars of a specific type and range of adaptation (Iwánska et al., 2020). This work aimed to evaluate the differences in growth, yield and photosynthetic responses of ten bread wheat genotypes, two of them were Egyptian genotypes, under normal and drought stress conditions.

\section{Materials and Methods}

\section{Plant materials and growing conditions:}

A set of 10 bread wheat genotypes were used in the current study comprised of 2 Egyptian cultivars, and 8 advanced inbred lines (AIL) obtained from CIMMYT (Table 1). These AIL lines were derived from different crosses and selected under different environments through shuttle breeding approach in CIMMYT. These 10 genotypes were sown using randomized complete block design in a strip plot arrangement with 3 replications. The after mentioned genotypes were grown during two growing seasons (2017/ 2018 and 2018 /2019) at the Agricultural Research Station, Faculty of Agriculture, Assiut University, Egypt. Both optimal and drought conditions were applied as follows: In the optimal condition, genotypes were irrigated regularly. While, in the drought condition, four irrigations were skipped, two during vegetative growth and two during flowering stage (Table 2). The land was prepared for cultivation using chisel plow and the experimental unit was $3 * 3.5 \mathrm{~m}$ consisting of 5 lines were planted in early December on the basis number of grains of 100 grains/line. Each genotype was represented by one row and the harvest was finally at the end of April.

\section{Plant traits:}

Plant height $(\mathrm{cm})$ was measured as the distance from the ground surface to the base of the main culm spike using 10 individual guarded stems from each genotype. 
Table 1. The name, pedigree, and origin of studied genotypes.

\begin{tabular}{|c|c|c|c|c|}
\hline $\begin{array}{l}\text { Code } \\
\text { No }\end{array}$ & Genotypes & Cross Name & Selection History & Origin \\
\hline 1 & $\mathrm{C} 103$ & KACHU \#1 & $\begin{array}{l}\text { CMSS97M03912T-040Y-020Y-030M-020Y-040M-4Y- } \\
\text { 2M-0Y }\end{array}$ & $\begin{array}{c}\text { MXI13- } \\
\text { 14IMULTTESTIGOS } \backslash 4\end{array}$ \\
\hline 2 & C108 & TAITA & CMSS08Y00140S-099Y-099M-099NJ-099NJ-4WGY-0B & $\begin{array}{l}\text { MXI13- } \\
\text { 14IM35ES22SAWHT\9 }\end{array}$ \\
\hline 3 & $\mathrm{C} 112$ & MUTUS//ND643/2*WBLL1 & CMSS08Y00224S-099Y-099M-099NJ-099NJ-1WGY-0B & $\begin{array}{l}\text { MXI13- } \\
\text { 14\M35ES22SAWHT\19 }\end{array}$ \\
\hline 5 & $\mathrm{C} 129$ & $\begin{array}{c}\text { CHYAK1*2/3/HUW234+LR } \\
\text { 34/PRINIA//PFAU/WEAVE } \\
\text { R }\end{array}$ & $\begin{array}{l}\text { CMSS08Y00931T-099TOPM-099Y-099M-099NJ-099NJ- } \\
\text { 1WGY-0B }\end{array}$ & $\begin{array}{l}\text { MXI13- } \\
\text { 14IM35ES22SAWHT } 192\end{array}$ \\
\hline 6 & $\mathrm{C} 134$ & $\begin{array}{l}\text { WHEAR//2*PRL/2*PASTOR } \\
\text { /3/QUAIU \#1 }\end{array}$ & CMSS08B00510S-099M-099NJ-099NJ-3WGY-0B & $\begin{array}{c}\text { MXI13- } \\
\text { 14\M35ES22SAWHT \109 }\end{array}$ \\
\hline 8 & $\mathrm{C} 148$ & $\begin{array}{l}\text { BECARD//KIRITATI/2*TRC } \\
\text { H/3/BECARD }\end{array}$ & CMSS08B00888T-099TOPY-099M-099NJ-35WGY-0B & $\begin{array}{c}\text { MXI13- } \\
\text { 14IM35ES22SAWHT } \backslash 166\end{array}$ \\
\hline 9 & Giza-168 & Giza-168 & MIL/Buc/SeriCM93046-8M-04-0M-2Y-OB & Egypt \\
\hline 10 & Sids-12 & Sids-12 & $\begin{array}{c}\text { BUC//7C/ALD/5/MAYA74/ON//1160.147/3/BB/GLL/4/C } \\
\text { HAT"S"/6/MAYA/VUL//CMH74A.63014*SX }\end{array}$ & Egypt \\
\hline
\end{tabular}

Table 2. Irrigation cycle for season (2017-2019).

\begin{tabular}{|c|c|c|}
\hline First season & Control & Drought \\
\hline $5 / 12 / 2017$ & \multicolumn{2}{|c|}{ Sowing } \\
\hline $25 / 12 / 2017$ & + & + \\
\hline $12 / 1 / 2018$ & + & - \\
\hline $27 / 1 / 2018$ & + & - \\
\hline $12 / 2 / 2018$ & + & - \\
\hline $26 / 2 / 2018$ & \multicolumn{2}{|c|}{ Sample collection } \\
\hline $27 / 2 / 2018$ & + & + \\
\hline $14 / 3 / 2018$ & + & - \\
\hline $1 / 4 / 2018$ & + & + \\
\hline $23 / 4 / 2018$ & \multicolumn{2}{|c|}{ Harvest } \\
\hline \multicolumn{3}{|c|}{ Second season } \\
\hline $2 / 12 / 2018$ & \multicolumn{2}{|c|}{ Sowing } \\
\hline $24 / 12 / 2018$ & + & + \\
\hline $10 / 1 / 2018$ & + & - \\
\hline $28 / 1 / 2019$ & + & - \\
\hline $17 / 2 / 2019$ & + & - \\
\hline $26 / 2 / 2019$ & \multicolumn{2}{|c|}{ Sample collection } \\
\hline $7 / 3 / 2019$ & + & + \\
\hline $20 / 3 / 2019$ & + & - \\
\hline $7 / 4 / 2019$ & + & + \\
\hline $1 / 5 / 2019$ & \multicolumn{2}{|c|}{ Harvest } \\
\hline
\end{tabular}

+ indicates irrigation was given, - irrigation was skipped 
Subsequently, the average plant height was calculated for each replication.

Chlorophyll content (A and B):

Chlorophyll was extracted, in test tubes, from a definite weight $(0.09 \mathrm{gm})$ of fresh healthy leaves in $10 \mathrm{ml}$ of $80 \%$ aqueous ethanol and heated in $70^{\circ} \mathrm{C}$ water bath for 12-15 minutes (all tubes were covered by glass marbles) until the leaf tissue turned colorless (Welfare et al., 1996). Then, the samples were immediately inserted in ice to cool down and adjusted to $10 \mathrm{ml}$ volume. Using spectrophotometer (Spectro 22 LaboMed, Inc), the extension of optical density of the extract was measured at 3 wavelengths of 470, 644 and 663 which are the maximum absorption of Chlorophyll A (Chl. a) and Chlorophyll b (Chl. b). These photosynthetic pigments were expressed as mg. $\mathrm{g}^{-1} \mathrm{FW}$. The used equations for this purpose were

Chl. $\mathrm{a}=(0.0127$ A663 - 0.00269 A644 $) \times$ extraction rtio

Chl. $b=(0.0229$ A645 - 0.00468 A663 $) \times$ extraction rtio

Spike length $(\mathrm{cm})$ was measured at harvesting as an average length of 10 spikes taken randomly from the middle of each plot or genotype. $100 \mathrm{GW}$ was recorded in grams $(\mathrm{g})$ by the mean weight of random 1000-grain samples. Grain yield (g) was weighted as grain yield for each genotype.

\section{Drought susceptibility index (DSI):}

Drought susceptibility index was calculated according to the method of Fischer and Maurer (1978). Yield of individual genotype was determining under stress (Yd) and favorable well-water (Yw) conditions. Average yield of all genotype under drought $(x d)$ and well-watered conditions ( $\times w)$ were used to calculate drought intensity (D) as: D $=(1-\quad \times \mathrm{d} / \times \mathrm{w})$. The mean drought susceptibility index (DSI) of individual genotype was calculated as: $\mathrm{S}=$ (1$\mathrm{Yd} / \mathrm{Yw}) / \mathrm{D}$. Genotypes with average susceptibility or tolerance to drought have "S" value of 1.0 values, less than 1.0 indicate less susceptibility and great tolerance to drought. Meanwhile, a value of $\mathrm{S}=0.0$ indicates maximum possible drought resistance mean no effect of drought on yield.

\section{Statistical and genetic analyses:}

The separate and combined analyses of variance of the evaluation of cultivars were done on plot mean basis according to Gomez and Gomez (1984). After testing the homogeneity of variance, LSD used to compare means according to (El-Rawi and Khalafalla 1980).

\section{Results and Discussions}

Data in table 3 indicated that the differences between the years were significant in all studied traits except for the length of the spike and the weight of 100 grains. Also, drought treatment affected all traits except chlorophyll b content. The interaction between years and drought treatment was significant for all traits. All the differences between the genotypes were significant. Also the differences were significant for the interaction between the genotypes and years except for the length of the spike. The interaction between the genotypes and treatments was significant for all traits and the differences in the effective between the patterns of genetic and transactions and years were all immaterial except spike length and the weight of the 100 grains. 
Table 3. Strip plot analysis combined of variance for growing tow season (2017/2018, 2018/2019).

\begin{tabular}{|l|c|c|c|c|c|c|c|}
\hline \multicolumn{1}{|c|}{ Source } & DF & PH & Chl a & Chl b & SL & 100GW & GY \\
\hline Year $(\mathbf{Y})$ & 1 & $5880^{* * *}$ & $8.13^{* * *}$ & $3.5^{* * *}$ & 2.78 & 0.1 & $804647.05^{* * *}$ \\
\hline Error A & 2 & 1.3 & 0.03 & 0.001 & 4.87 & 0.05 & 10309 \\
\hline Treatment (T) & 1 & $2050.13^{* * *}$ & $0.28^{* *}$ & 0.03 & $69.39^{* * *}$ & $2.91^{* * *}$ & $8332009.67^{* * *}$ \\
\hline T x Y & 1 & $73.63^{*}$ & $1.18^{* * *}$ & $0.52^{* * *}$ & $4.7^{*}$ & $1.61^{* * *}$ & $285339.13^{* * *}$ \\
\hline Error B & 4 & 7.23 & 0.01 & 0.01 & 0.4 & 0.03 & 3687.63 \\
\hline Genotypes (G) & 9 & $66.61^{* * * *}$ & $0.11^{* * *}$ & $0.07^{* * *}$ & $1.85^{*}$ & $0.7^{* * *}$ & $62709.53^{* * *}$ \\
\hline G x Y & 9 & $40.09^{* * *}$ & $0.08^{* * *}$ & $0.1^{* * *}$ & 1.57 & $0.1^{*}$ & $59184.77^{* * *}$ \\
\hline Error C & 36 & 5 & 0.01 & 0.004 & 0.84 & 0.04 & 3453.93 \\
\hline G x T & 9 & $113.67^{* * *}$ & $0.16^{* * *}$ & $0.12^{* * *}$ & $2.33^{*}$ & $0.15^{* *}$ & $101607.21^{* * * *}$ \\
\hline G x T x Y & 9 & $41.65^{* * *}$ & $0.14^{* * *}$ & $0.12^{* * *}$ & 1.52 & 0.04 & $30940.38^{* * * *}$ \\
\hline Error & 36 & 6.18 & 0.01 & 0.004 & 1.06 & 0.05 & 4127.78 \\
\hline
\end{tabular}

$\mathrm{PH}=$ Plant height, $\mathrm{SL}=$ Spike Length, $\mathrm{GY}=$ grain yield.

Significance $*=\mathrm{p}<0.05, * *=\mathrm{p}<0.01, * * *=\mathrm{p}<0.001$.

$*, * *, * * *$ Significant at $0.05,0.01$ and 0.001 levels of probability; respectively

\section{Chlorophyll a content:}

The combined average of Chl. a content under normal irrigation conditions ranged from 0.72 for AIL142 to 1.08 for Giza 168 with an average of 0.92 . Five genotypes were significantly surpassed the average Chl. a content under control. Chl. a contents ranged from 0.44 for AIL108 to 0.79 for AIL148 with an average of 0.64 . Generally, Chl. a contents were decreased (Table 5). AIL120, AIL148 and Giza168 recorded the highest $\mathrm{Chl}$. a contents under drought conditions. Thus these genotypes could be used to improve chlorophyll a content. The reductions in chlorophyll a contents due to water stress in the first, second and over both seasons were 29.11, 33.62 and $30.64 \%$ compared to normal irrigation conditions, respectively.

DSI indicated the most tolerant genotypes of drought at a rate of 0.02 to AIL120, and the most sensitive to drought at a rate of 2.24 to AIL134 in the first season indicating that the most tolerant genotypes of drought at a rate of 0.07 to AIL134, and the most sensitive to drought at a rate of 1.64 to AIL108 in the second season. It indicated the most tolerant genotypes of drought at a rate of 0.48 to AIL142, and the most sensitive to drought at a rate of 1.50 to AIL108 in means over two seasons. The results showed that net photosynthesis and transpiration rate was severely reduced under water deficit condition. These results agreed with Condon et al. (2002).

\section{2- Chlorophyll b content:}

The combined average of chlorophyll $b$ (Chl. b) contents under normal irrigation conditions ranged from 0.53 for AIL129 to 0.93 for AIL148 with an average of 0.68 six genotypes were significantly surpassed the average Chl. b content Under control, Chl. b contents ranged from 0.37 for Giza168 to 0.55 for AIL148 with an average of 0.45 . Three genotypes were significantly surpassed the Chl. b contents under drought (Table 6). Moreover, AIL120 and AIL148 recorded the higher Chl. b under drought stress conditions. While the reductions in Chl. b content due to water stress in the first, second and over both seasons were 29.39, 42.01 and $34.02 \%$ compared to normal irrigation conditions, respectively. 
Table 4. Mean chlorophyll A content, (nm), reduction\% (R) and drought susceptibility index (DSI) for the two seasons under normal irrigation and water stress conditions.

\begin{tabular}{|c|c|c|c|c|c|c|c|c|c|c|c|c|c|c|c|}
\hline \multirow[b]{2}{*}{ Genotype } & \multicolumn{5}{|c|}{$2017-2018$} & \multicolumn{5}{|c|}{$2018-2019$} & \multicolumn{5}{|c|}{ Means over two years } \\
\hline & Control & Drought & Mean & $\mathbf{R \%}$ & DSI & Control & Drought & Mean & R\% & DSI & Control & Drought & Mean & R\% & DSI \\
\hline AIL103 & 0.95 & 0.85 & 0.90 & 10.68 & 0.37 & 0.78 & 0.42 & 0.60 & 46.15 & 1.37 & 0.87 & 0.63 & 0.75 & 26.66 & 0.87 \\
\hline AIL108 & 1.07 & 0.65 & 0.86 & 39.63 & 1.36 & 0.54 & 0.24 & 0.39 & 55.22 & 1.64 & 0.81 & 0.44 & 0.62 & 44.83 & 1.50 \\
\hline AIL112 & 1.31 & 0.69 & 1.00 & 47.34 & 1.63 & 0.58 & 0.39 & 0.49 & 32.76 & 0.97 & 0.95 & 0.54 & 0.74 & 42.87 & 1.30 \\
\hline AIL120 & 1.16 & 1.15 & 1.16 & 0.67 & 0.02 & 0.65 & 0.40 & 0.52 & 38.58 & 1.15 & 0.91 & 0.78 & 0.84 & 14.25 & 0.59 \\
\hline AIL129 & 1.15 & 0.90 & 1.02 & 22.03 & 0.76 & 0.59 & 0.46 & 0.53 & 21.28 & 0.63 & 0.87 & 0.68 & 0.77 & 21.78 & 0.69 \\
\hline AIL134 & 1.75 & 0.61 & 1.18 & 65.29 & 2.24 & 0.37 & 0.36 & 0.36 & 2.28 & 0.07 & 1.06 & 0.48 & 0.77 & 54.36 & 1.16 \\
\hline AIL142 & 0.90 & 0.81 & 0.85 & 10.13 & 0.35 & 0.54 & 0.43 & 0.49 & 20.51 & 0.61 & 0.72 & 0.62 & 0.67 & 14.05 & 0.48 \\
\hline AIL148 & 1.16 & 0.97 & 1.07 & 16.38 & 0.56 & 0.84 & 0.62 & 0.73 & 26.18 & 0.78 & 1.00 & 0.79 & 0.90 & 20.49 & 0.67 \\
\hline Giza168 & 1.41 & 1.05 & 1.23 & 25.54 & 0.88 & 0.75 & 0.50 & 0.63 & 32.99 & 0.98 & 1.08 & 0.78 & 0.93 & 28.13 & 0.93 \\
\hline Sids12 & 1.34 & 0.98 & 1.16 & 26.88 & 0.92 & 0.65 & 0.34 & 0.49 & 46.90 & 1.40 & 0.99 & 0.66 & 0.83 & 33.40 & 1.16 \\
\hline Mean & 1.22 & 0.87 & & & & 0.63 & 0.42 & & & & 0.92 & 0.64 & & & \\
\hline $\begin{array}{c}\text { F Test } \\
\text { irrigation (I) }\end{array}$ & \multicolumn{5}{|c|}{$* *$} & \multicolumn{5}{|c|}{$* *$} & \multicolumn{5}{|c|}{$* *$} \\
\hline R LSD $(\mathbf{G})$ & \multicolumn{5}{|c|}{0.13} & \multicolumn{5}{|c|}{0.05} & \multicolumn{5}{|c|}{0.07} \\
\hline RLSD I $\times \mathbf{G}$ & \multicolumn{5}{|c|}{0.50} & \multicolumn{5}{|c|}{0.11} & \multicolumn{5}{|c|}{5.64} \\
\hline Reduction \% & \multicolumn{5}{|c|}{29.11} & \multicolumn{5}{|c|}{33.62} & \multicolumn{5}{|c|}{30.64} \\
\hline
\end{tabular}


As for the drought susceptibility index, it indicated the most tolerant genotypes of drought at a rate of 0.21 to AIL129, and the most sensitive to drought at a rate of 2.01 to AIL134 in the first season. It indicated the most tolerant genotypes of drought at a rate of 0.29 to sids 12 , and the most sensitive to drought at a rate of 1.86 to Giza168 in the second season. It indicated the most tolerant genotypes of drought at a rate of 0.51 to AIL129, and the most sensitive to drought at a rate of 1.50 to Giza168 in means over two seasons. The results showed that drought stress reduces leaf chlorophyll (Ommen et al. 1999) mainly due to damage to chloroplasts caused by the genesis of reactive oxygen species (ROS) (Smirnoff 1995). Terminal drought caused decreased of chlorophyll content and protein content compared to normal irrigation levels (Moaveni 2011; Almeselmani et al. 2012).

\section{Plant height:}

The combined average of plant height under normal irrigation conditions ranged from 97.50 for sids12 to 108.67 for AIL108 with an average of 101.97 four genotypes were significantly surpassed the average plant height under control plant height ranged from 85.50 for AIL134 to 97.00 for AIL148 with an average of 93.00 six genotypes were significantly surpassed the average plant height under drought. The obtained results indicating that plant height in these genotypes was height under normal irrigation than under drought conditions (Table 4). AIL129 and AIL148 recorded the highest length of wheat individuals under drought conditions thus these genotypes could be used to improve plant height. The reductions in plant height due to water stress in the first, second and over both seasons were $10.51,7.29$ and $8.79 \%$ compared to normal irrigation conditions, respectively.

Drought susceptibility index (DSI) indicated that the most tolerant genotypes of drought at a rate of .10 to AIL148, and the most sensitive to drought at a rate of 2.04 to AIL134 in the first season. It indicated the most tolerant genotypes of drought at a rate of .10 to AIL148, and the most sensitive to drought at a rate of 2.04 to AIL134 in the second season. It indicated the most tolerant genotypes of drought at a rate of 0.04 to Giza 168, and the most sensitive to drought at a rate of 2.44 to AIL134 in means over two seasons. It indicated the most tolerant genotypes of drought at a rate of.25to AIL148, and the most sensitive to drought at a rate of 2.24 to AIL1108 in means over two seasons. Mohamed (1999) found that plant height was reduced by water stress and Dencic et al (2000) came to the same conclusion.

\section{Spike length (cm):}

The combined average of spike length under normal irrigation conditions ranged from 11.75 for AIL103 to 13.50 for sids12 with an average of 12.66. Four genotypes were significantly surpassed the average plant height under control spike length ranged from 10.00 for sids 12 to 11.75 for AIL112 with an average of 11.06. Six genotypes were significantly surpassed the average spike length under drought (Table 7). The reductions in spike length due to water stress in the first, second and over both seasons were 10.08, 15.13 and $12.61 \%$ compared to normal irrigation conditions, respectively.

As for the drought susceptibility index, it indicated the most tolerant genotypes of 
Table 5. Mean chlorophyll B content (nm), reduction\% (R) and drought susceptibility index (DSI) for the two seasons under normal irrigation and water stress conditions

\begin{tabular}{|c|c|c|c|c|c|c|c|c|c|c|c|c|c|c|c|}
\hline \multirow[b]{2}{*}{ Genotype } & \multicolumn{5}{|c|}{$2017-2018$} & \multicolumn{5}{|c|}{$2018-2019$} & \multicolumn{5}{|c|}{ Means over two years } \\
\hline & Control & Drought & Mean & $\mathbf{R} \%$ & DSI & Control & Drought & Mean & $\mathbf{R} \%$ & DSI & Control & Drought & Mean & $\mathbf{R} \%$ & DSI \\
\hline AIL103 & 0.64 & 0.51 & 0.57 & 21.51 & 0.73 & 0.64 & 0.37 & 0.51 & 42.19 & 1.00 & 0.64 & 0.44 & 0.54 & 31.81 & 0.87 \\
\hline AIL108 & 0.72 & 0.58 & 0.65 & 19.44 & 0.66 & 0.38 & 0.27 & 0.32 & 29.77 & 0.71 & 0.55 & 0.42 & 0.49 & 23.02 & 0.69 \\
\hline AIL112 & 0.96 & 0.72 & 0.84 & 24.88 & 0.85 & 0.64 & 0.14 & 0.39 & 78.07 & 1.86 & 0.80 & 0.43 & 0.61 & 46.26 & 1.35 \\
\hline AIL120 & 0.89 & 0.63 & 0.76 & 29.03 & 0.99 & 0.53 & 0.46 & 0.50 & 13.70 & 0.33 & 0.71 & 0.54 & 0.63 & 23.29 & 0.66 \\
\hline AIL129 & 0.65 & 0.61 & 0.63 & 6.15 & 0.21 & 0.41 & 0.27 & 0.34 & 34.15 & 0.81 & 0.53 & 0.44 & 0.49 & 16.98 & 0.51 \\
\hline AIL134 & 1.48 & 0.61 & 1.04 & 59.08 & 2.01 & 0.38 & 0.25 & 0.32 & 34.21 & 0.81 & 0.93 & 0.43 & 0.68 & 54.00 & 1.41 \\
\hline AIL142 & 0.64 & 0.58 & 0.61 & 9.38 & 0.32 & 0.54 & 0.34 & 0.44 & 35.94 & 0.86 & 0.59 & 0.46 & 0.52 & 21.48 & 0.59 \\
\hline AIL148 & 0.93 & 0.67 & 0.80 & 28.44 & 0.97 & 0.64 & 0.44 & 0.54 & 31.14 & 0.74 & 0.78 & 0.55 & 0.67 & 29.53 & 0.85 \\
\hline Giza168 & 0.93 & 0.62 & 0.77 & 33.20 & 1.13 & 0.58 & 0.13 & 0.35 & 78.17 & 1.86 & 0.75 & 0.37 & 0.56 & 50.48 & 1.50 \\
\hline Sids12 & 0.81 & 0.59 & 0.70 & 27.16 & 0.92 & 0.27 & 0.24 & 0.26 & 12.14 & 0.29 & 0.54 & 0.41 & 0.48 & 23.38 & 0.61 \\
\hline Mean & 0.86 & 0.61 & & & & 0.50 & 0.29 & & & & 0.68 & 0.45 & & & \\
\hline $\begin{array}{c}\text { F Test } \\
\text { irrigation (I) }\end{array}$ & \multicolumn{5}{|c|}{$*$} & \multicolumn{5}{|c|}{$* *$} & \multicolumn{5}{|c|}{ N.S } \\
\hline R LSD(G) & \multicolumn{5}{|c|}{0.12} & \multicolumn{5}{|c|}{0.03} & \multicolumn{5}{|c|}{0.02} \\
\hline RLSD I × G & \multicolumn{5}{|c|}{0.35} & \multicolumn{5}{|c|}{0.11} & \multicolumn{5}{|c|}{0.14} \\
\hline Reduction \% & \multicolumn{5}{|c|}{29.39} & \multicolumn{5}{|c|}{42.01} & \multicolumn{5}{|c|}{34.02} \\
\hline
\end{tabular}
*, ** Significant at 0.05 and 0.01 levels of probability; respectively 
Table 6. Mean plant height, cm, reduction\% (R) and drought susceptibility index (DSI) for the two seasons under normal irrigation and water stress conditions.

\begin{tabular}{|c|c|c|c|c|c|c|c|c|c|c|c|c|c|c|c|}
\hline \multirow[b]{2}{*}{ Genotype } & \multicolumn{5}{|c|}{$2017-2018$} & \multicolumn{5}{|c|}{$2018-2019$} & \multicolumn{5}{|c|}{ Means over two years } \\
\hline & Control & Drought & Mean & $\mathrm{R} \%$ & DSI & Control & Drought & Mean & $\mathbf{R} \%$ & DSI & Control & Drought & Mean & $\mathbf{R} \%$ & DSI \\
\hline AIL103 & 92.00 & 85.00 & 88.50 & 7.61 & 0.72 & 104.33 & 99.00 & 101.67 & 5.11 & 0.70 & 98.17 & 92.00 & 95.08 & 6.28 & 0.71 \\
\hline AIL108 & 106.67 & 86.67 & 96.67 & 18.75 & 1.78 & 110.67 & 105.00 & 107.83 & 5.12 & 0.70 & 108.67 & 95.83 & 102.25 & 11.81 & 1.24 \\
\hline AIL112 & 99.00 & 88.00 & 93.50 & 11.11 & 1.06 & 110.33 & 96.00 & 103.17 & 12.99 & 1.78 & 104.67 & 92.00 & 98.33 & 12.10 & 1.42 \\
\hline AIL120 & 95.00 & 84.00 & 89.50 & 11.58 & 1.10 & 111.67 & 103.00 & 107.33 & 7.76 & 1.07 & 103.33 & 93.50 & 98.42 & 9.52 & 1.08 \\
\hline AIL129 & 93.67 & 88.00 & 90.83 & 6.05 & 0.58 & 110.67 & 104.00 & 107.33 & 6.02 & 0.83 & 102.17 & 96.00 & 99.08 & 6.04 & 0.70 \\
\hline AIL142 & 97.00 & 86.00 & 91.50 & 11.34 & 1.08 & 104.00 & 101.33 & 102.67 & 2.57 & 0.35 & 100.50 & 93.67 & 97.08 & 6.80 & 0.72 \\
\hline AIL148 & 92.00 & 91.00 & 91.50 & 1.09 & 0.10 & 106.00 & 103.00 & 104.50 & 2.83 & 0.39 & 99.00 & 97.00 & 98.00 & 2.02 & 0.25 \\
\hline Giza168 & 96.67 & 87.00 & 91.83 & 10.00 & 0.95 & 102.33 & 102.00 & 102.17 & 0.32 & 0.04 & 99.50 & 94.50 & 97.00 & 5.02 & 0.50 \\
\hline Sids12 & 85.00 & 82.00 & 83.50 & 3.53 & 0.34 & 110.00 & 98.00 & 104.00 & 10.91 & 1.50 & 97.50 & 90.00 & 93.75 & 7.69 & 0.92 \\
\hline Mean & 95.50 & 85.47 & & & & 108.43 & 100.53 & & & & 101.97 & 93.00 & & & \\
\hline
\end{tabular}


Table 7. Mean spike length, (cm), reduction\% (R) and drought susceptibility index (DSI) for the two seasons under normal irrigation and water stress conditions.

\begin{tabular}{|c|c|c|c|c|c|c|c|c|c|c|c|c|c|c|c|}
\hline \multirow[b]{2}{*}{ Genotype } & \multicolumn{5}{|c|}{$2017-2018$} & \multicolumn{5}{|c|}{$2018-2019$} & \multicolumn{5}{|c|}{ Means over two years } \\
\hline & Control & Drought & Mean & $\mathbf{R \%}$ & DSI & Control & Drought & Mean & $\mathbf{R \%}$ & DSI & Control & Drought & Mean & $\mathbf{R} \%$ & DSI \\
\hline AIL103 & 11.50 & 10.50 & 11.00 & 8.70 & 0.86 & 12.00 & 10.50 & 11.25 & 12.50 & 0.83 & 11.75 & 10.50 & 11.13 & 10.64 & 0.84 \\
\hline AIL108 & 13.00 & $\begin{array}{c}1 \\
2.25\end{array}$ & 12.63 & 5.77 & 0.57 & 12.00 & 11.00 & 11.50 & 8.33 & 0.55 & 12.50 & 11.63 & 12.06 & 7.00 & 0.56 \\
\hline AIL112 & 13.17 & 12.50 & 12.83 & 5.06 & 0.50 & 13.33 & 11.00 & 12.17 & 17.50 & 1.16 & 13.25 & 11.75 & 12.50 & 11.32 & 0.83 \\
\hline AIL120 & 12.17 & 11.17 & 11.67 & 8.22 & 0.82 & 12.67 & 10.50 & 11.58 & 17.11 & 1.13 & 12.42 & 10.83 & 11.63 & 12.75 & 0.97 \\
\hline AIL129 & 13.33 & 11.00 & 12.17 & 17.50 & 1.74 & 13.00 & 11.50 & 12.25 & 11.54 & 0.76 & 13.17 & 11.25 & 12.21 & 14.56 & 1.25 \\
\hline AIL134 & 12.00 & 11.00 & 11.50 & 8.33 & 0.83 & 12.17 & 11.83 & 12.00 & 2.74 & 0.18 & 12.08 & 11.42 & 11.75 & 5.52 & 0.50 \\
\hline AIL142 & 13.00 & 11.00 & 12.00 & 15.38 & 1.53 & 13.00 & 11.67 & 12.33 & 10.26 & 0.68 & 13.00 & 11.33 & 12.17 & 12.82 & 1.10 \\
\hline AIL148 & 12.50 & 11.00 & 11.75 & 12.00 & 1.19 & 12.50 & 11.50 & 12.00 & 8.00 & 0.53 & 12.50 & 11.25 & 11.88 & 10.00 & 0.86 \\
\hline Giza168 & 12.33 & 11.83 & 12.08 & 4.05 & 0.40 & 12.50 & 9.50 & 11.00 & 24.00 & \begin{tabular}{|l|}
1.59 \\
\end{tabular} & 12.42 & 10.67 & 11.54 & 14.09 & 0.99 \\
\hline Sids12 & 13.50 & 11.50 & 12.50 & 14.81 & 1.47 & 13.50 & 8.50 & 11.00 & 37.04 & 2.45 & 13.50 & 10.00 & 11.75 & 25.93 & 1.96 \\
\hline Mean & 12.65 & 11.38 & & & & 12.67 & 10.75 & & & & 12.66 & 11.06 & & & \\
\hline $\begin{array}{c}\text { F Test } \\
\text { irrigation (I) }\end{array}$ & \multicolumn{5}{|c|}{ * } & \multicolumn{5}{|c|}{$* *$} & \multicolumn{5}{|c|}{$* * *$} \\
\hline R LSD(G) & \multicolumn{5}{|c|}{0.72} & \multicolumn{5}{|c|}{0.68} & \multicolumn{5}{|c|}{0.84} \\
\hline $\mathbf{R L S D} \mathbf{I} \times \mathbf{G}$ & \multicolumn{5}{|c|}{2.58} & \multicolumn{5}{|c|}{4.40} & \multicolumn{5}{|c|}{5.59} \\
\hline Reduction \% & \multicolumn{5}{|c|}{10.08} & \multicolumn{5}{|c|}{15.13} & \multicolumn{5}{|c|}{12.61} \\
\hline
\end{tabular}


Table 8. Mean 100 - grain weight (g), reduction\% (R) and drought susceptibility index (DSI) for the two seasons under normal irrigation and water stress conditions.

\begin{tabular}{|c|c|c|c|c|c|c|c|c|c|c|c|c|c|c|c|}
\hline \multirow[b]{2}{*}{ Genotype } & \multicolumn{5}{|c|}{$2017-2018$} & \multicolumn{5}{|c|}{$2018-2019$} & \multicolumn{5}{|c|}{ Means over two years } \\
\hline & Control & Drought & Mean & $\mathrm{R} \%$ & DSI & Control & Drought & Mean & $\mathrm{R} \%$ & DSI & Control & Drought & Mean & $\mathbf{R} \%$ & DSI \\
\hline AIL103 & 4.69 & 3.93 & 4.31 & 16.25 & 1.46 & 4.75 & 4.25 & 4.50 & 10.46 & 2.98 & 4.72 & 4.09 & 4.40 & 13.33 & 2.22 \\
\hline AIL108 & 4.85 & 4.30 & 4.58 & 11.33 & 1.02 & 4.85 & 4.71 & 4.78 & 2.89 & 0.82 & 4.85 & 4.51 & 4.68 & 7.11 & 0.92 \\
\hline AIL112 & 4.52 & 3.85 & 4.19 & 14.96 & 1.34 & 4.40 & 4.35 & 4.38 & 1.14 & 0.32 & 4.46 & 4.10 & 4.28 & 8.14 & 0.83 \\
\hline AIL120 & 4.75 & 4.50 & 4.63 & 5.33 & 0.48 & 4.69 & 4.65 & 4.67 & 0.85 & 0.24 & 4.72 & 4.57 & 4.65 & 3.11 & 0.36 \\
\hline AIL129 & 4.77 & 4.52 & 4.64 & 5.31 & 0.48 & 4.93 & 4.90 & 4.92 & 0.61 & 0.17 & 4.85 & 4.71 & 4.78 & 2.92 & 0.32 \\
\hline AIL134 & 5.02 & 4.34 & 4.68 & 13.49 & 1.21 & 4.83 & 4.80 & 4.82 & 0.48 & 0.14 & 4.92 & 4.57 & 4.75 & 7.11 & 0.67 \\
\hline AIL142 & 5.25 & 4.65 & 4.95 & 11.47 & 1.03 & 5.03 & 5.00 & 5.02 & 0.60 & 0.17 & 5.14 & 4.82 & 4.98 & 6.15 & 0.60 \\
\hline AIL148 & 5.42 & 4.51 & 4.96 & 16.74 & 1.50 & 4.92 & 4.85 & 4.88 & 1.36 & 0.39 & 5.17 & 4.68 & 4.92 & 9.42 & 0.94 \\
\hline Giza168 & 4.84 & 4.22 & 4.53 & 12.88 & 1.16 & 4.43 & 4.02 & 4.23 & 9.40 & 2.68 & 4.64 & 4.12 & 4.38 & 11.21 & 1.92 \\
\hline Sids12 & 4.57 & 4.44 & 4.51 & 2.70 & 0.24 & 4.55 & 4.18 & 4.37 & 8.13 & 2.32 & 4.56 & 4.31 & 4.44 & 5.41 & 1.28 \\
\hline Mean & 4.87 & 4.32 & & & & 4.74 & 4.57 & & & & 4.80 & 4.45 & & & \\
\hline $\begin{array}{c}\text { F Test } \\
\text { irrigation (I) }\end{array}$ & \multicolumn{5}{|c|}{$* * *$} & \multicolumn{5}{|c|}{ N.S } & \multicolumn{5}{|c|}{$* * *$} \\
\hline R LSD(G) & \multicolumn{5}{|c|}{0.02} & \multicolumn{5}{|c|}{0.27} & \multicolumn{5}{|c|}{0.14} \\
\hline RLSD I × G & \multicolumn{5}{|c|}{0.70} & \multicolumn{5}{|c|}{0.93} & \multicolumn{5}{|c|}{0.51} \\
\hline Reduction \% & \multicolumn{5}{|c|}{11.15} & \multicolumn{5}{|c|}{3.51} & \multicolumn{5}{|c|}{7.38} \\
\hline
\end{tabular}


drought at a rate of 0.40 to Giza168, and the most sensitive to drought at a rate of 1.74 to AIL129 in the first season. It indicated the most tolerant genotypes of drought at a rate of 0.18 to AIL134, and the most sensitive to drought at a rate of 2.45 to sids 12 in the second season. It indicated the most tolerant genotypes of drought at a rate of 0.50 to AIL134, and the most sensitive to drought at a rate of 1.96 to sids12 in means over two seasons. Abd El-Karim (1991) found that spike length was significantly affected by water stress treatments and wheat genotypes. Furthermore, the mean square due to water stress $x$ genotype was significant for spike length. (Kheiralla et al. 2004) reported that spike length was highly significantly affected by years, water stress treatments and genotype. Moreover, exposing wheat plants to drought at tailoring, booting and milk stages reduced spike length.

\section{100 grains weight $(100 G W)$ :}

The combined average of $100 \mathrm{GW}$ under normal irrigation conditions ranged from 4.46 for AIL112 to 5.17 for AIL148 with an average of 4.80 . Five genotypes were significantly surpassed the average $100 \mathrm{GW}$ under control, 100 grain weight ranged from 4.09 for AIL103 to 4.82 for AIL142 with an average of 4.45 six genotypes were significantly surpassed the average $100 \mathrm{GW}$ under drought (Table 8). The reductions in $100 \mathrm{GW}$ due to water stress in the first, second and over both seasons were $11.15,3.51$ and $7.38 \%$ compared to normal irrigation conditions, respectively.

As for the drought susceptibility index, it indicated the most tolerant genotypes of drought at a rate of 0.24 to sids 12 and the most sensitive to drought at a rate of 1.50 to AIL148 in the first season. It indicated the most tolerant genotypes of drought at a rate of 0.14 to AIL134, and the most sensitive to drought at a rate of 2.98 to Giza168 in the second season. It indicated the most tolerant genotypes of drought at a rate of 0.32 to AIL129, and the most sensitive to drought at a rate of 2.22 to AIL103 in means over two seasons. Sayed and Hi (1982) showed that the $1000 \mathrm{GW}$ was reduced by $12 \%$ under drought stress. Tawfelis (2006) reported that wheat genotypes differently responded to different environmental conditions and drought and heat stress reduced number of $1000 \mathrm{GW}$ to $9.06 \%$ and $22.06 \%$, respectively, compared to normal.

\section{Grain yield per genotype (g):}

The combined average of grain yield per genotype under normal irrigation conditions ranged from 526.89 for AIL148 to 927.64 for AIL129 with an average of 686.35. Four genotypes were significantly surpassed the average grain yield per genotype Under control, grain yield per genotype ranged from 66.08 for AIL142 to 229.58 for AIL148 with an average of 159.35 six genotypes were significantly surpassed the average grain yield per genotype under drought (Table 8). The reductions in grain yield/plot due to water stress in the first, second and over both seasons were $77.29,76.44$ and $76.78 \%$ compared to normal irrigation conditions, respectively.

As for the drought susceptibility index, it indicated the most tolerant genotypes of drought at a rate of .80 to AIL112, and the most sensitive to drought at a rate of 1.14 to AIL142 in the first season. It indicated the most tolerant 
Table 9. Mean grain yield / genotype / (g), reduction\% (R) and drought susceptibility index (DSI) for the two seasons under normal irrigation and water stress conditions.

\begin{tabular}{|c|c|c|c|c|c|c|c|c|c|c|c|c|c|c|c|}
\hline \multirow[b]{2}{*}{ Genotype } & \multicolumn{5}{|c|}{$2017-2018$} & \multicolumn{5}{|c|}{$2018-2019$} & \multicolumn{5}{|c|}{ Means over two years } \\
\hline & Control & Drought & Mean & R\% & DSI & Control & Drought & Mean & R\% & DSI & Control & Drought & Mean & $\mathbf{R} \%$ & DSI \\
\hline AIL103 & 545.79 & 108.19 & 326.99 & 80.18 & 1.04 & 628.36 & 151.04 & 389.70 & 75.96 & 0.99 & 587.07 & 129.61 & 358.34 & 77.92 & 1.02 \\
\hline AIL108 & 773.74 & 155.88 & 464.81 & 79.85 & 1.03 & 911.90 & 167.92 & 539.91 & 81.59 & 1.07 & 842.82 & 161.90 & 502.36 & 80.79 & 1.05 \\
\hline AIL112 & 354.78 & 136.08 & 245.43 & 61.65 & 0.80 & 786.63 & 317.83 & 552.23 & 59.60 & 0.78 & 570.71 & 226.95 & 398.83 & 60.23 & 0.79 \\
\hline AIL120 & 561.68 & 66.75 & 314.22 & 88.12 & 1.14 & 1256.05 & 193.05 & 724.55 & 84.63 & 1.11 & 908.87 & 129.90 & 519.38 & 85.71 & 1.12 \\
\hline AIL129 & 782.44 & 131.48 & 456.96 & 83.20 & 1.08 & 1072.84 & 115.17 & 594.00 & 89.27 & 1.17 & 927.64 & 123.32 & 525.48 & 86.71 & 1.12 \\
\hline AIL134 & 653.22 & 157.51 & 405.36 & 75.89 & 0.98 & 866.41 & 185.39 & 525.90 & 78.60 & 1.03 & 759.81 & 171.45 & 465.63 & 77.44 & 1.01 \\
\hline AIL142 & 441.20 & 51.15 & 246.17 & 88.41 & 1.14 & 803.23 & 81.02 & 442.13 & 89.91 & 1.18 & 622.21 & 66.08 & 344.15 & 89.38 & 1.16 \\
\hline AIL148 & 620.70 & 217.47 & 419.08 & 64.96 & 0.84 & 433.08 & 241.70 & 337.39 & 44.19 & 0.58 & 526.89 & 229.58 & 378.24 & 56.43 & 0.71 \\
\hline Giza168 & 390.84 & 80.42 & 235.63 & 79.42 & 1.03 & 776.81 & 252.88 & 514.85 & 67.45 & 0.88 & 583.82 & 166.65 & 375.24 & 71.46 & 0.96 \\
\hline Sids12 & 432.69 & 157.37 & 295.03 & 63.63 & 0.82 & 634.74 & 218.76 & 426.75 & 65.54 & 0.86 & 533.71 & 188.06 & 360.89 & 64.76 & 0.84 \\
\hline Mean & 555.71 & 126.23 & & & & 817.00 & 192.47 & & & & 686.35 & 159.35 & & & \\
\hline $\begin{array}{c}\text { F Test } \\
\text { irrigation (I) }\end{array}$ & \multicolumn{5}{|c|}{$* * *$} & \multicolumn{5}{|c|}{$* * *$} & \multicolumn{5}{|c|}{$* * *$} \\
\hline R LSD(G) & \multicolumn{5}{|c|}{42.07} & \multicolumn{5}{|c|}{85.63} & \multicolumn{5}{|c|}{40.09} \\
\hline RLSD I × G & \multicolumn{5}{|c|}{133.17} & \multicolumn{5}{|c|}{289.88} & \multicolumn{5}{|c|}{145.83} \\
\hline Reduction \% & \multicolumn{5}{|c|}{77.29} & \multicolumn{5}{|c|}{76.44} & \multicolumn{5}{|c|}{76.78} \\
\hline
\end{tabular}


genotypes of drought at a rate of .58 to AIL148, and the most sensitive to drought at a rate of 1.18 to AIL142 in the second season. It indicated the most tolerant genotypes of drought at a rate of .71 to AIL148, and the most sensitive to drought at a rate of 1.16 to AIL142 in means over two seasons. Kobata et al (1992) showed that the grain yield was reduced under water stress by $33 \%$. While, Salem (2005) reported that full irrigation treatment significantly maximized grain yield / ha and Dencic et al. (2000) found that decreasing soil moisture caused significant reduction in grain yield.

\section{References}

Abd El-Karim, A. (1991). 'Evaluation of some wheat germplasm under some stresses', M.Sc.Thesis, Fac. Agric., Assiut Univ., Egypt.

Almeselmani, M., Saud, A.A.R, Al-zubi, K., Hareri, F., Al-nassan, M., Ammar, M., A, Kanbar, O. Z., AlNaseef, H., Al-nator, A., Algazawy, A. and Abu Al-sael, H. (2012). 'Physiological attributes associated to water deficit tolerance of Syrian durum wheat varieties', Exper. Agric. Horti. , 8, pp. 21-41.

Bartels, D., Sunkars R. (2005). 'Drought and salt tolerance in plants', Critical Reviews in Plant Science, 24(1),pp. 23-58.

doi: 10.1080/07352680590910410

Begcy, K., Walia H. (2015). 'Drought stress delays endosperm development and miss regulates genes associated with cytoskeleton organization and grain quality proteins in developing wheat seeds', Plant Science, 240, pp.109-119. doi: 10.1016/j.plantsci.2015.08.024
Cattivelli, L., Rizza, F., Badeck, F., Mazzucotelli, E., Mastrangelo, A., Francia, E., Marè, C. Tondelli, A. and Stanca, A.M (2008).' Drought tolerance improvement in crop plants: an integrated view from breeding to genomics', Field crops research, 105(1-2), pp. 1-14. doi: 10.1016/j.fcr.2007.07.004

Chaves, M. S., Martinelli, J. A., WespGuterres, C., Graichen, F. A. S., Brammer, S. P., Scagliusi, S. M., ... and Consoli, L. (2013). 'The importance for food security of maintaining rust resistance in wheat', Food security, 5(2), pp. 157176. doi: 10.1007/s12571-013-0248-X

Condon, A. G., Richards, R. A., Rebetzke, G. J., and Farquhar, G. D. (2002).' Improving intrinsic water-use efficiency and crop yield', Crop science, 42(1), pp. 122-131. doi: 10.2135/cropsci2002.1220

Denčić, S., Kastori, R., Kobiljski, B., and Duggan, B. (2000). 'Evaluation of grain yield and its components in wheat cultivars and landraces under near optimal and drought conditions', Euphytica, 113(1), pp. 43-52.

doi: 10.1023/A:1003997700865

Al-Rawi, K., and Khalaf-Allah, A. (1980). 'Design and analysis of agricultural experiments', El Mousel Univ., Iraq, 19, pp. 487.

FAO- OECA (2018). 'Food and agriculture organization of the united nations, crop prospect and food situation', http://www.fao.org/giews/english/cp fs.

Farooq, M., Hussain, M., and Siddique, K. (2014). 'Drought stress in wheat 
during flowering and grain-filling periods', Critical Reviews in Plant Sciences, 33(4), pp. 331-349. doi: 10.1080/07352689.2014.875291

Fischer, R., and Maurer, R. (1978). 'Drought resistance in spring wheat cultivars. I. Grain yield responses', Australian Journal of Agricultural Research, 29(5), pp. 897-912. doi: 10.1071/AR9780897

Gomez, K., and Gomez, A. (1984).' Statistical procedures for agricultural research', John Wiley \& Sons.

Huseynova, I. (2012).' Photosynthetic characteristics and enzymatic antioxidant capacity of leaves from wheat cultivars exposed to drought', Biochimica et Biophysica Acta (BBA)-Bioenergetics, 1817(8), pp.1516-1523.

doi: 10.1016/j.bbabio.2012.02.037

Iqbal, J. (2019).' Morphological, physiological and molecular markers for the adaptation of wheat in drought condition', Asian Journal of Biotechnology and Genetic Engineering, pp.1-13.

Iwańska, M., Paderewski, J., Stępień, M., and Rodrigues, P.c. (2020).' Adaptation of Winter Wheat Cultivars to Different Environments': A Case Study in Poland, Agronomy, 10(5), pp. 632. doi: 10.3390/agronomy10050632

Ji, X., Shiran, B., Wan, J., Lewis, D. C., Jenkins, C. L.D, Condon, A. G., Richards, R.A and Dolferus, R. (2010). 'Importance of pre-anthesis anther sink strength for maintenance of grain number during reproductive stage water stress in wheat', Plant,
Cell \& Environment, 33(6), pp. 926942. doi: 10.1111/j.13653040.2010.02130.x

Keyvan, S. (2010). 'The effects of drought stress on yield, relative water content, proline, soluble carbohydrates and chlorophyll of bread wheat cultivars', J. Anim. Plant Sci, 8(3), pp.1051-1060.

Kheiralla, K., El-Morshidy, M., M.H. Motawea and Saeid,A. (2004). 'Performance and stability of some wheat genotypes under normal and water stress conditions', Assiut J.Agric. Sci., 35, pp. 74-94.

Kobata, T., Palta, J. A., and Turner, N. C. (1992). 'Rate of development of postanthesis water deficits and grain filling of spring wheat', Crop science, 32(5), pp.1238-1242. doi: 10.2135/cropsci1992.0011183X0032 $00050035 \mathrm{x}$

Mafakheri, A., Siosemardeh, A., Bahramnejad, B., Struik, P., and Sohrabi, Y. (2010). 'Effect of drought stress on yield, proline and chlorophyll contents in three chickpea cultivars', Australian journal of crop science,4(8), pp. 580.

Moaveni, P. (2011). 'Effect of water deficit stress on some physiological traits of wheat (Triticum aestivum)', Agric. Sci. Res. J, 1(1), pp. 64-68.

Mohamed, A. (1999). 'Promising durum wheat genotypes under normal and stress growing conditions in northern Sudan', Barley and Wheat Newsletter.

Nikolaeva, M., Maevskaya, S., Shugaev, A., and Bukhov, N. (2010).'Effect of 
drought on chlorophyll content and antioxidant enzyme activities in leaves of three wheat cultivars varying in productivity', Russian Journal of Plant Physiology, 57(1), pp. 87-95. doi: 10.1134/S1021443710010127

Ommen, O., Donnelly, A., Vanhoutvin, S., Van Oijen, M., and Manderscheid, R. (1999). 'Chlorophyll content of spring wheat flag leaves grown under elevated $\mathrm{CO} 2$ concentrations and other environmental stresses within the

'ESPACE-wheat 'project', European Journal of Agronomy, 10(3-4), pp. 197-203. doi: 10.1016/S1161-0301(99)00011-8

Rahaie, M., Xue, G., and Schenk, P. (2013).'The role of transcription factors in wheat under different abiotic stresses', Abiotic stress-plant responses and applications in agriculture, pp. 367-385. doi: $10.5772 / 54795$

Rizk, A., and Sherif, M. (2014).' Effect of soil moisture depletion on the yield of wheat under sprinkler irrigation at Toshka area, Egypt', Middle East J. of Agric. Res, 3(4), pp.981-987.

Salem, M.A. (2005). 'Effect of nitrogen rates and irrigation regimes on yield and yield components of bread wheat (Triticum aestivum L.) Genotypes under newly reclaimed land conditions'. J. Agric. Sci., Mansoura Univ., Egypt, 30, pp. 6481-6490.

Savary, S., Ficke, A., Aubertot, J. N., and Hollier, C. (2012). 'Crop losses due to diseases and their implications for global food production losses and food security'. Food Secur 4, pp.
519-537. doi: 10.1007/s12571-0120200-5

Sayed, H. and HI, S. (1982). 'Response of wheat and triticale cultivars grown under field conditions to drought stress', Wheat information Service, 167, pp. 23-28.

Smirnoff, N. (1995). 'Metabolic flexibility in relation to the environment. Environment and plant metabolism: flexibility and acclimation', Oxford: Bios Scientific publishers, pp.1-13.

Tawfelis, M. (2006). 'Using biplot technique in wheat breeding under different environmental stresses', Egypt J. Plant Breed, 10, pp. 167200.

Tian, F.B., Young, J., and Lai, J. (2014).' Improving power-extraction efficiency of a flapping plate: From passive deformation to active control', Journal of Fluids and Structures, 51, pp. 384-392. doi: 10.1016/j.jfluidstructs.2014.07.013

Welfare, K., Flower, T.J., Taylor, G., and Yeo, A.R., (1996). 'Additive and antagonistic effects of ozone and salinity on growth, ion contents and gas exchange of five varieties of rice (Oryza sativa L.)', Environmental Pollution, 92(3), pp. 257-266. doi: 10.1016/0269-7491(96)00003-6

Zhao, H., Xu, Z., Zhao, J., and Huang, W. (2017).' A drought rarity and evapotranspiration-based index as a suitable agricultural drought indicator', Ecological Indicators, 82, pp.530-538.

doi: 10.1016/j.ecolind.2017.07.024 